\title{
Using sheep lines with mutations in single genes to better understand ovarian function
}

\author{
Jennifer L Juengel, George H Davis and Kenneth P McNatty ${ }^{1}$ \\ AgResearch Centre for Reproduction and Genomics, AgResearch Limited, Invermay Agricultural Centre, \\ Puddle Alley, Private Bag 50034, Mosgiel 9053, New Zealand and ${ }^{1}$ School of Biological Sciences, \\ Victoria University of Wellington, Wellington, New Zealand
}

Correspondence should be addressed to J L Juengel; Email: jenny.juengel@agresearch.co.nz

\begin{abstract}
Livestock populations have been subjected to strong selection pressure to improve reproductive success, and this has led to the identification of lines of animals with increased fecundity. These animals provide a rich biological resource for discovery of genes and regulatory mechanisms that underpin improved reproductive success. To date, three genes, all related to the transforming growth factor $\beta$ pathway, have been identified as having mutations that lead to alterations in ovulation in sheep. In addition, several other sheep lines have been identified with putative mutations in single genes with major effects on ovulation rate. This review is focused on the identification of the mutations affecting ovulation rate and how these discoveries have provided new insights into control of ovarian function.

Reproduction (2013) 146 R111-R123
\end{abstract}

\section{Genetic mutations affecting ovulation rate in sheep}

Multiple mutations in three different genes, all related to the transforming growth factor $\beta$ (TGFB) superfamily pathway, have been identified in various sheep lines around the world (Table 1). Sheep lines with other putative major genes have also been established, some of which do not appear to interact with the TGFB superfamily and thus may be affecting other pathways yet to be discovered.

\section{BMP15 mutations}

At least six different mutations have been identified in the BMP15 gene (Galloway et al. 2000, Hanrahan et al. 2004, Bodin et al. 2007, Martinez-Royo et al. 2008, Monteagudo et al. 2009, Lahoz et al. 2011) wherein ewes heterozygous for the mutations have increased ovulation rates and those homozygous for the mutations are infertile. While all the mutations have similar general effects on fertility, there are subtle differences, as the increases in ovulation rate observed in the heterozygous animals (Table 1) vary from 35 to 100\% (McNatty et al. 2004). While this could be related to differences in the background genetics of the various sheep lines, it has also been hypothesized to be the result of different effects of the mutations on protein function. Those mutations potentially affecting interaction of BMP15 with its receptors are suggested to have greater effects on ovulation rate given the complex nature of the interactions between BMP15 and GDF9 with their receptors (McNatty et al. 2004). Recently, two new mutations in BMP15 have been described in the French Grivette and the Polish Olkuska breeds. These lead to hyper prolificacy, particularly in ewes homozygous for the mutation, without causing sterility (Demars et al. 2012). Based on the known physiological activities of the proteins, this phenotype would be predicted if the mutation decreased, rather than abolished, the biological activity of the protein (Fig. 1).

\section{GDF9 mutations}

Studies on mice showed that GDF9 (Dong et al. 1996), but not BMP15 (Yan et al. 2001), was essential for normal follicular growth. Therefore, the question arose as to whether one, but not the other, of these two proteins would be important for normal follicular development, with the key player showing species-dependent activity. Related to this was the key question of whether GDF9 would also be essential for normal follicular growth in sheep. The first indications that GDF9 was indeed essential for normal follicular development in sheep came through active immunization studies. Adult sheep immunized against GDF9 ceased having reproductive cycles with ovarian follicular development affected from the earliest stages (Juengel et al. 2002). Shortly after these findings were published, a mutation in GDF9 was 
Table 1 Known mutations affecting BMP15, GDF9 and BMPR1B genes, the resulting effect on the encoded proteins and the effects on ovulation rate of ewes heterozygous and homozygous for the mutations.

\begin{tabular}{|c|c|c|c|c|c|c|c|}
\hline \multirow[b]{2}{*}{ Gene } & \multirow[b]{2}{*}{ Line/breed } & \multirow[b]{2}{*}{ Allele } & \multirow{2}{*}{$\begin{array}{l}\text { Coding } \\
\text { residue }(\mathrm{aa})\end{array}$} & \multirow{2}{*}{$\begin{array}{l}\text { Amino } \\
\text { acid change }\end{array}$} & \multirow[b]{2}{*}{ Predicted effect } & \multicolumn{2}{|c|}{ Change in ovulation rate } \\
\hline & & & & & & Heterozygous & Homozygous \\
\hline \multirow[t]{6}{*}{ BMP15 } & $\mathrm{Bel} / \mathrm{Cam}$ & $\mathrm{FecX} \mathrm{X}^{\mathrm{G}}$ & 239 & Gln-STOP & No mature region made & $+35-42 \%$ & POF \\
\hline & Belclare & $\mathrm{FecX}^{\mathrm{B}}$ & 367 & Ser-lle & Disrupt binding to type 2 receptor & $+95 \%$ & POF \\
\hline & Inverdale & Fec $X^{\prime}$ & 299 & Val-Asp & Reduced concentration of mature BMP15 & $+61 \%$ & POF \\
\hline & Hanna & $\mathrm{Fec} \mathrm{X}^{\mathrm{H}}$ & 291 & Glu-STOP & Truncated non-functional protein & $+67 \%$ & POF \\
\hline & Lacaune & $\mathrm{FecX}^{\mathrm{L}}$ & 321 & Cys-Tyr & Reduced conc. of BMP15 & $+100 \%$ & POF \\
\hline & Rasa Arag & $F e c X^{R}$ & 154 & Frame shift & No mature region made & $+38-46 \%$ & POF \\
\hline \multirow[t]{3}{*}{ GDF9 } & $\mathrm{Bel} / \mathrm{Cam}$ & $\mathrm{FecG}^{\mathrm{H}}$ & 395 & Ser-Phe & Disrupted binding to type 1 receptor & $+87 \%$ & POF \\
\hline & Thoka & Thoka & 427 & Ser-Arg & Disrupted binding to type 2 receptor & +32\% (lambing rate) & POF \\
\hline & Santa Inês & $\mathrm{FecG}^{\mathrm{E}}$ & 345 & Phe-Cys & Alters dimer formation & $+10 \%$ (not significant) & $+82 \%$ \\
\hline$B M P R 1 B$ & Booroola & $\mathrm{FecB}$ & 249 & Gln-Arg & Alters intercellular signalling (?) & $+86 \%$ & $+206 \%$ \\
\hline
\end{tabular}

Bel/Cam, Belclare/Cambridge; POF, primary ovarian failure; Rasa Arag, Rasa Aragonesa.

identified in the Belclare and Cambridge breeds in which animals heterozygous for the mutation had increased ovulation rate and those that were homozygous were sterile (Hanrahan et al. 2004). This mutation, which introduces a non-conservative amino acid change, is thought to disrupt interaction with a type 1 TGFB family receptor (McNatty et al. 2004). Subsequently, a separate mutation in GDF9 in the Thoka line with a similar, although not identical, phenotype was identified (Nicol et al. 2009). The mutation in the Thoka line was predicted to disrupt binding to the type 2 receptor (McNatty et al. 2004, Juengel et al. 2005). Further, a mutation in GDF9 has been linked to increased ovulation rate when ewes are homozygous for the nonconservative change in an amino acid predicted to be involved in dimer formation. No change in ovulation rate was observed in heterozygous ewes (Silva et al. 2011). This phenotype is similar to that described for the French Grivette sheep with mutations in BMP15. Based on the known physiological activities of the proteins, this phenotype would be predicted if the mutation decreased, rather than abolished, the biological activity of the protein. Similarly, a single-strand conformation polymorphism has been identified in the encoded proregion of the GDF9 gene of the Small Tailed Han sheep with genotypes of $A A$ and $A B$ (Chu et al. 2004). The $A A$ genotype had a larger litter size than the $A B$ genotype, suggestive of higher ovulation rates in the homozygous vs the heterozygous carriers. However, interpretation of these data sets is complicated by the lack of any animals with the BB genotype, potentially due to the rarity of the $B$ allele, and the knowledge that mutations in both $B M P 15$ and $B M P R 1 B$ are also present, but not fixed, in the Small Tailed Han sheep (Davis et al. 2006b, Chu et al. 2007).

\section{BMPR1B mutation}

Although a mutation in the $B M P R 1 B$ gene has been identified in several sheep lines selected for increased fecundity (Davis et al. 2002, 2006b, Chu et al. 2007), the same mutation (Mulsant et al. 2001, Souza et al. 2001, Wilson et al. 2001) has been observed in each of these lines. In contrast to the relatively restricted expression of the GDF9 and BMP15 genes, BMPR1B is widely expressed throughout the body and the mutation likely subtly affects multiple tissue types including the pituitary and the adrenal glands (Wilson et al. 2001, Souza et al. 2003, Xu et al. 2010). However, the major effect of this mutation appears to be at the level of the ovary (Campbell et al. 2003, Souza et al. 2003). The mutation introduces a non-conservative amino acid change in the kinase domain of the protein (Mulsant et al. 2001, Souza et al. 2001, Wilson et al. 2001). Original studies showed that the mutated receptor, while potentially having higher basal activity, did not show increased receptor activity in response to ligand treatment (Fabre et al. 2003). However, others have failed to observe similar effects when the mutation was introduced into the mouse Bmpr1b gene (Ho \& Bernard 2009), and the effects of the Booroola mutation on the kinase activity of ovine BMPR1B have not been verified (Edwards et al. 2009). Thus, it is unclear how this mutation affects the receptor to cause changes in ovarian function.

\section{Gene interactions and other as yet unidentified mutations}

Several ewes that carry mutations in more than a single gene have been identified and the combination of these genes has a synergistic effect with very high ovulation rates being reached in some animals. For example, the average ovulation rates (average number of eggs released by animals that can ovulate for any one cycle) of ewes heterozygous for mutations in both GDF9 and BMP15 was $252-321 \%$ of controls (Hanrahan et al. 2004) while ewes heterozygous for mutations in BMP15 and BMPR1B had average ovulation rates $258 \%$ of controls (Davis et al. 1999). Interactions among these genes and other as yet unidentified mutations have also been demonstrated. For example, the Woodlands gene, an unidentified mutation on the X-chromosome (Davis et al. 2001), 

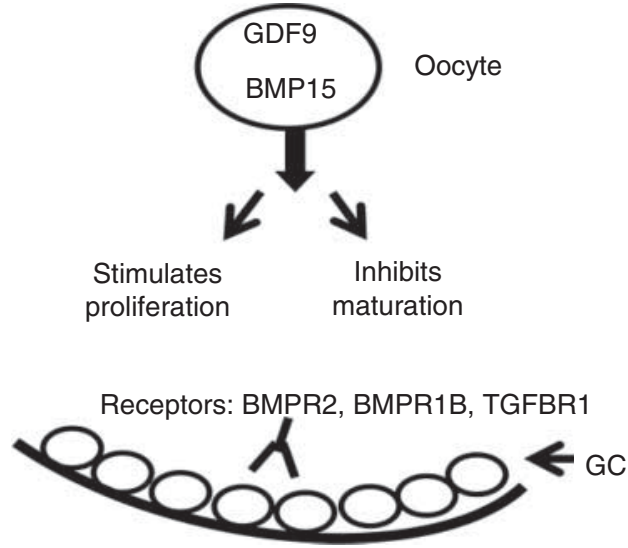

B
Wild-type ewes

$$
1
$$

Follicular types

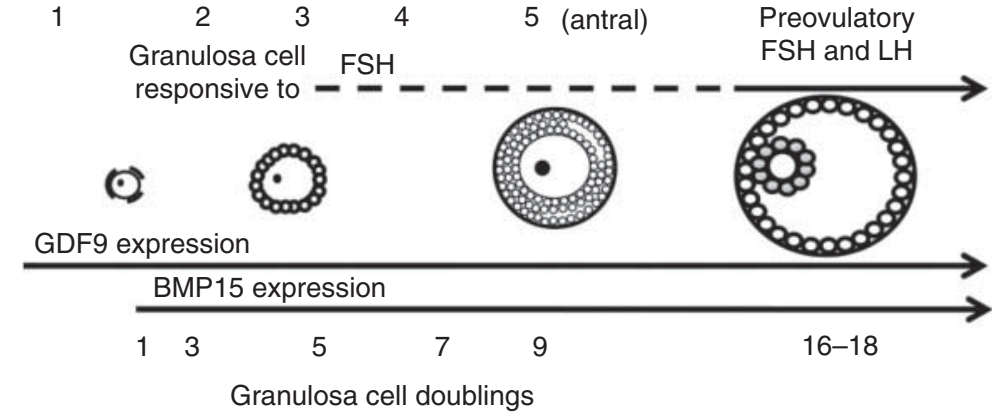

Homozygous carriers of inactivating mutations in GDF9 or BMP15 Follicular types
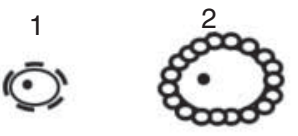

$$
11
$$

No normal development past type 2 stage
Heterozygous carriers of inactivating GDF9 or BMP15 mutations (heterozygous or homozygous carriers of BMPR1B mutation)

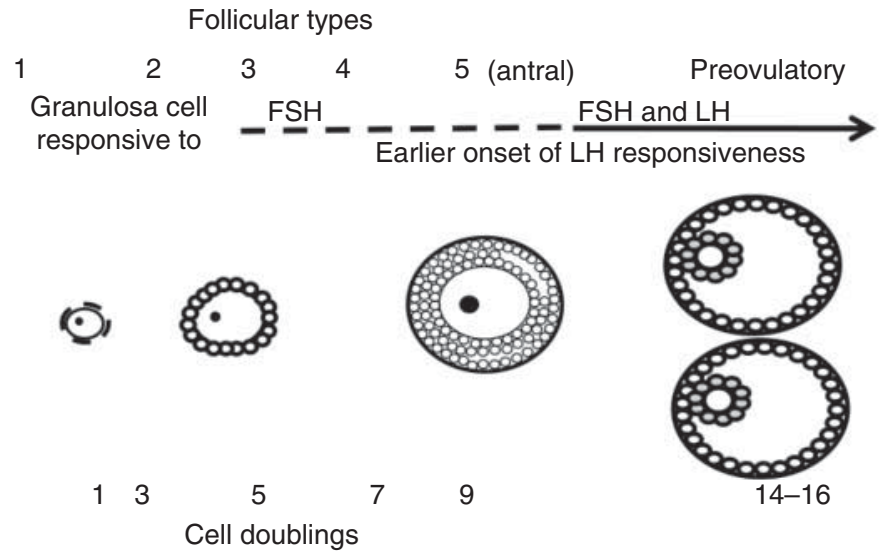

Figure 1 The roles of GDF9 and BMP15 in the regulation of ovarian follicular development. (A) GDF9 and BMP15 are produced by the oocyte and act through receptors located on the granulosa cells (GC). Both GDF9 and BMP15 utilize a receptor complex composed of two types of serine-threonine kinases. BMPR2 is the type 2 receptor used by both GDF9 and BMP15 with GDF9 using TGFBR1 (ALK5) and BMP15 using BMPR1B (ALK6) as the type 1 receptors. The Booroola mutation is in BMPR1B and this may account for the synergistic interactions between the Booroola and Inverdale (BMP15) mutations. Together, GDF9 and BMP15 stimulate proliferation of granulosa cells and inhibit gonadotrophin-induced maturation. (B) Most follicles are present in the ovary as non-growing type 1 (primordial) follicles. Oocytes in these follicles express GDF9 but not BMP15. Growing follicles express both GDF9 and BMP15 in the oocytes and the granulosa cells become gonadotrophin responsive, and first express FSH receptors. Later in development, the granulosa cells express both FSH and LH receptors and continuous development becomes critically dependent on the gonadotrophins. Initially, a number of follicles begin to grow but the granulosa cells of the maturing follicles produce increasing amounts of steroid and inhibin that lead to inhibition of FSH production from the pituitary gland. Thereafter, only those follicles that have developed LH receptors in the granulosa cells continue to develop when the FSH concentration declines. In wild-type ewes, typically only one or two of the developing antral follicles reach this critical maturational stage when the FSH concentration has declined during the preovulatory period. In turn, this then restricts the number of follicles ovulating to those with LH-responsive granulosa cells. Ewes homozygous for mutations in either GDF9 or BMP15 fail to make sufficient quantities of biologically active protein to stimulate granulosa cell proliferation and thus normal follicular growth is prevented from the type 2 (primary) stage of development. Granulosa cells in ewes that are heterozygous for mutations in either GDF9 or BMP15, or heterozygous or homozygous for mutations in BMPR1B, most likely have reduced secretions of GDF9 and/or BMP15 or an attenuated GDF9 and/or BMP15 response. It is proposed that this results in reduced proliferation but an earlier acquisition of LH receptivity in the granulosa cells in follicles at a smaller size. The concentrations of steroids and inhibin are related to the number of granulosa cells in developing follicles. As more follicles have developed $\mathrm{LH}$ receptors while FSH concentrations decline, then more follicles will continue to grow during the preovulatory period, thereby leading to higher ovulation rates in these genotypes. 
appears to act synergistically with the Inverdale and Booroola genes, with ewes heterozygous for all the three genes having ovulation rates as high as 13 compared with 1-2 for wild-type controls (Davis et al. 2008). A possible mechanism for these interactions was identified when it was shown that BMP15 mRNA levels were decreased in animals carrying the Woodlands gene (Feary et al. 2007) or homozygous for the Booroola gene (Crawford et al. 2011) compared with their wild-type contemporaries. However, BMP15 mutations have also been observed in flocks carrying other putative major genes influencing ovulation rate wherein the effect is additive rather than synergistic. This includes the animals carrying the Lacaune gene $\left(F e c L^{L}\right)$ and the BMP15 mutation in the Lacaune breed $\left(F e c X^{L}\right)$ (Drouilhet et al. 2009). Investigations into the underlying physiology of ewes homozygous for the Lacaune $\left(F e c L^{L}\right)$ gene further highlighted the fact that different physiological mechanisms appeared to be acting to increase ovulation rate in this line of ewes (Drouilhet et al. 2010). Preliminary publications indicate a mutation in intron 7 of B4GALNT2, which causes ectopic expression of the mRNA in the ovarian follicle and an aberrant pattern of glycosylated proteins in granulosa cells (Mansanet et al. 2012). The proteins with atypical glycosylation include members of the TGFB superfamily, and thus, the question still does remain whether this mutation interacts with the TGFB pathway. Analysis of another putative gene segregating in the AgResearch Fertility flock, the Davisdale, also indicates an additive effect with the Inverdale mutation (Juengel et al. 2011c). Thus, it would not be unexpected to find that pathways other than the TGFB superfamily are likely to also be key regulators of ovulation rate in sheep.

Other sheep lines have been identified with putative single genes affecting ovulation rate. These include the Wishart line (Davis et al. 2006a), a potential second gene in the New Zealand Booroola line (Juengel et al. 2008) and the Belle-Ile breed (Davis 2004). However, little is known about the underlying physiology that leads to the observed increases in ovulation rate/litter size or whether any of the aforementioned sheep lines have perturbations in the TGFB superfamily pathway. Identifying the mutations underlying these phenotypes, as well as the pathways affected, is likely to offer new insights into the range of physiological factors regulating ovulation rate.

\section{Mechanisms of action of GDF9 and BMP15 and the involvement of the $B M B R 1 B$ receptor}

One complicating factor in understanding the actions of GDF9 and BMP15 is the apparent differences among species in the role of these factors in regulating ovarian follicular development. Considerable knowledge regarding the potential roles of GDF9, BMP15 and BMPR1B has been gained from studying the physiology of ewes carrying mutations in the genes encoding these proteins (Souza et al. 2003, 2004, McNatty et al. 2005a, Fabre et al. 2006) and this is the focus of this review. However, data from other species will be included when it is unavailable for sheep. Also outside the scope of this review is in-depth discussion of the structure of GDF9 and BMP15, the receptors and signalling pathways activated by GDF9 and BMP15 as well as the potential ligands for BMPR1B, and the functions of GDF9 and BMP15 as assessed in vitro. Information on these aspects is reported extensively elsewhere (Shimasaki et al. 2004, Juengel \& McNatty 2005, Gilchrist et al. 2008, Otsuka et al. 2011, Paulini \& Melo 2011). However, it is important to note that mRNA encoding GDF9 and BMP15 are tightly co-regulated in multiple species (Crawford \& McNatty 2012) and GDF9 and BMP15 have synergistic affects at the level of the cell (McNatty et al. 2005b, $2005 c$ ). Thus, when examining the physiology of these molecules, the cooperative nature of these molecules is a very important consideration.

Phenotypically, ewes homozygous for mutations in GDF9 or BMP15 are similar, with growth of follicles blocked at a very early stage of development (Braw-Tal et al. 1993, Nicol et al. 2009). This supports the roles of both GDF9 and BMP15 in proliferation of granulosa cells very early in the growth of the follicle (Fig. 1). In most cases, in ewes lacking biologically active GDF9 or BMP15, normal follicular development beyond the primary stage of development is not observed, albeit there are differences between the GDF9 mutations with abnormal follicles up to the antral stage observed in some lines (Hanrahan et al. 2004, McNatty et al. 2005a). An interesting feature observed in ewes lacking either GDF9 or BMP15 is the continued growth of the oocyte to a size that is similar to that seen in an antral follicle (Braw-Tal et al. 1993, Juengel et al. 2000, Nicol et al. 2009). This results in the formation of abnormal follicles with a single layer of flattened granulosa cells surrounding enlarged oocytes, suggesting that at least some of the growth of the oocyte can occur independently of the granulosa cells. Eventually, however the oocytes die, and structures containing granulosa cells and degenerating oocytes are commonly observed. Based on gene expression data, it is thought that the granulosa cells subsequently form 'nodules' containing residual granulosa cells (Juengel et al. 2000, Nicol et al. 2009).

In ewes lacking active BMP15, development of benign ovarian cysts or tumours occurs (Braw-Tal et al. 1993, McLeod et al. 1995). These can have different morphologies ranging from a large follicle-like cyst structure, to a semi-solid structure containing granulosalike cells, to cells with morphology similar to that observed in the corpus luteum, although without an extensive blood supply (Braw-Tal et al. 1993, Juengel et al. 2000). While these structures have been observed to grow and regress on the ovary throughout the life of the ewe (Braw-Tal et al. 1993, McLeod et al. 1995), 
longevity studies have shown no evidence of metastasis of the tumours over the natural lifetime of these animals. In the limited number of ewes homozygous for the GDF9 mutation that have been examined, similar structures have not been observed (Nicol et al. 2009). The cessation of follicular development at an early stage of development in ewes lacking active GDF9 or BMP15 also disturbs the normal feedback loops between the ovary and hypothalamus and pituitary, and hence, gonadotrophin levels are elevated (Braw-Tal et al. 1993, McLeod et al. 1995, Nicol et al. 2009). The exception to this observation is when benign ovarian cysts or tumours develop as these tumours can produce hormones that affect gonadotrophin secretion (Braw-Tal et al. 1993, McLeod et al. 1995). The lack of normal ovarian follicular development also affects the development of the uterus. Adult ewes have a reproductive tract with morphology similar to that observed in a young lamb (Davis et al. 1992, Nicol et al. 2009). Analysis of the uterus of homozygous Inverdale animals showed suppression of uterine development (Hayashi et al. 2008). However, it is important to note that the effects on gonadotrophin secretion and uterine development are thought to be indirect due to the absence of normal developing antral follicles.

Ewes heterozygous for mutations in BMP15 (Inverdale) or homozygous for mutations in BMPR1B (Booroola) have also been studied intensively (Fig. 1). As expected, given the known interactions between the Inverdale and Booroola genes (Davis et al. 1999), as well as the identification of BMPR1B as the receptor for BMP15 (Moore et al. 2003), there are similarities in the changes in physiology observed with these mutations; however, there are also differences. The mRNA encoding BMP15 is first expressed in the primary (type 2) follicle (Galloway et al. 2000), and thus, the effects of BMP15 are thought to be limited to the growing follicle. In contrast, BMPR $1 B$ mRNA is expressed in the ovary before and during formation of the follicles and the mutation would appear to affect ovarian follicles from the primordial stage onwards. Differences in follicle and oocyte size and cellular organelles have been observed when comparing primordial follicles from ewes homozygous for the Booroola mutation to their wild-type contemporaries (Reader et al. 2012). Whether the numbers of follicles formed are influenced by the Booroola mutation is unclear as different studies have drawn different conclusions, with some studies showing increased numbers of follicles (Smith et al. 1994) and others indicating that the number of follicles may be reduced in ewes homozygous for the Booroola mutation (Ruoss et al. 2009).

For both the Booroola and the Inverdale animals, a general hypothesis can be developed regarding the mechanisms increasing ovulation rate (Souza et al. 2003, Juengel et al. 2004b, Fabre et al. 2006). In both cases, while the number of ovulating follicles increases, the total number of granulosa cells from the ovulatory follicles, and thus the total amount of granulosa cellsecreted products such as oestradiol and inhibin, does not change (McNatty et al. 1985, Shackell et al. 1993, Souza et al. 2003, Juengel et al. 2004b). This occurs as a consequence of a reduction in the size of the ovulatory follicle and number of granulosa cells present within each follicle. In this manner, endocrine communication between the ovary and the hypothalamus/pituitary remains the same. The follicle therefore develops characteristics of an ovulatory follicle at a smaller size. This can be demonstrated through the increased proportions of smaller diameter follicles in Booroola and Inverdale animals with granulosa cells capable of responding to $\mathrm{LH}$ in vitro (McNatty et al. 2009, Crawford et al. 2011). Originally, granulosa cells from Booroola and Inverdale animals were thought to have an increased responsiveness to $\mathrm{FSH}$, but it has been shown recently that this is not the case. The original data showing increased responsiveness to FSH (Shackell et al. 1993) were most likely due to $\mathrm{LH}$ contamination in the partially purified preparation of the $\mathrm{FSH}$ utilized at that time (McNatty et al. 2009). The earlier onset of $\mathrm{LH}$ responsiveness in both Inverdale and Booroola ewes permits smaller follicles to survive during the time of suppressed gonadotrophin secretion that occurs during selection of the ovulatory follicle. In this manner, more follicles can advance to ovulation.

Studies have also been undertaken to determine how the BMPR1B receptor mutation affects the responsiveness of granulosa cells to BMPs. While there are some differences in the literature regarding which BMPs are produced by the ovine ovarian follicle, it is clear that there are other potential ligands in addition to BMP15 for BMPR1B in growing ovarian follicles (Campbell et al. 2006, Juengel et al. 2006). Another factor that complicates the interpretation of the results comparing responsiveness of granulosa cells from ewes homozygous for the Booroola mutation to their wildtype contemporaries is the aforementioned differences in the diameter of the ovulatory follicle. Therefore, follicles of similar diameter are likely to represent different developmental stages when comparing Booroola to wild-type animals. Notwithstanding these complexities, granulosa and theca cells in small antral follicles from ewes homozygous for the Booroola mutation appear to be more sensitive to BMPs as well as IGF and gonadotrophins (Campbell et al. 2006). Based on the differential activities of the BMPs, this increased sensitivity was proposed to underlie the enhanced differentiation of ovarian follicles in ewes homozygous for the Booroola mutation. The increased sensitivity to BMPs in homozygous Booroola animals has also been observed in pituitary cells (Young et al. 2008), supporting the hypothesis that the mutation increases sensitivity of the receptor to BMPs. However, others showed a decreased sensitivity to GDF5 and BMP4 in granulosa cells from small follicles from homozygous Booroola 
ewes when assessing their effects on progesterone production (Fabre et al. 2003). Again, interpretation of these data is complicated by differences in developmental stages for the same-sized follicles as responsiveness to GDF5 and BMP4 also decreased as follicular size increased. Thus, it is uncertain whether the mutation in the receptor increases or decreases the sensitivity of the receptor to its ligands.

Both Booroola and Inverdale ewes treated with exogenous gonadotrophins (i.e. treatment to induce multiple ovulations) show an increased ovulation rate response when compared with their wild-type contemporaries (McNatty et al. 2006a). In preliminary studies, increased ovulation rates following administration of exogenous gonadotrophins have also been observed in ewes heterozygous for the Woodlands gene when compared with wild-type contemporaries (J L Juengel, unpublished results), suggesting that the increased responsiveness to exogenous gonadotrophins in vivo is a common feature of animals with mutations that affect the TGFB superfamily pathway. It was recently discovered that there may be a second gene affecting ovulation rate in the New Zealand flock of Booroola ewes. Animals thought to be carrying the second putative gene that are also heterozygous for the Booroola mutation have an enhanced basal ovulation rate but lack the increased responsiveness to exogenous gonadotrophins observed in ewes carrying only the Booroola mutation (Juengel et al. 2008). Thus, the increased responsiveness in vivo to exogenous gonadotrophins observed in the ewes with mutations affecting the TGFB superfamily pathway is unlikely to be simply related to the increased basal ovulation rates of these animals. The physiological mechanisms of action that underlie the increased responsiveness to exogenous gonadotrophins are unclear. The increased ovulation rate observed in ewes with mutations in TGFB superfamily pathway may relate to the ability of FSH to recruit more follicles for preovulatory maturation from the relatively large pool of small antral follicles (Dufour et al. 2000). However, it is important to note that the effects of the Booroola mutation on follicle numbers are inconsistent (Smith et al. 1994, Ruoss et al. 2009). In addition, the acquisition of $\mathrm{LH}$ responsiveness in granulosa cells in a greater proportion of the pool of small antral follicles may allow more follicles to undergo preovulatory maturation (McNatty et al. 2009, Crawford et al. 2011).

Embryo transfer studies have shown that the increased ovulation rate in response to exogenous gonadotrophins resulted in an increase in transferable embryos in the Booroola, but not in the Inverdale, ewes (McNatty et al. 2006a). The inability of the increased ovulation rate observed in the Inverdale animals to translate into a significant increase in transferable embryos was an interesting observation. While no differences in embryo survival have been noted in animals heterozygous for inactivating mutations in BMP15 (Davis et al. 1993), or those immunized against BMP15 (Juengel et al. 2011b), addition of BMP15 to culture media improves blastocyst rates in IVM/IVF procedures (Hussein et al. 2006). Thus, it may be that reduced BMP15 secretion by the oocyte results in poorer oocyte quality when the system is 'stressed', as might be expected when exogenous gonadotrophin is used to recruit a greater number of follicles for ovulation. This effect could be independent of the regulation of the number of follicles ovulated. The results from the Booroola ewes are more difficult to interpret, as these embryo transfer studies were carried out prior to identification of the mutation and may have been confounded by the method used to determine the phenotype of the ewes. Genotype selection was based on an extreme ovulation rate difference relative to wild types (e.g. ewes classified as homozygous when ovulation rate $\geq 7$ and wild type when $\leq 2$ ). The recent findings of a potential second gene increasing ovulation rate in the flock makes it likely that at least some of these animals may have been carrying a second gene influencing selection of the ovulatory follicle.

\section{The use of immunization to mimic the phenotypes observed in ewes with mutations in GDF9, BMP15 and BMBR1B}

The phenotypes of ewes with mutations affecting the TGFB superfamily have potential benefits for modulating fertility in a diverse range of mammals. Consequently, experimental procedures to mimic the infertile and highly fecund phenotypes have been explored in animals not carrying these mutations. As it was known that mutations in BMP15 were inactivating, immunoneutralization of the protein was a logical strategy to emulate the effects of the mutation. Another strategic approach was to inhibit binding of BMP15 to target cells using antibodies specific for the extracellular domain of its receptor BMPR1B. While initial studies using active immunization against BMP15 and GDF9 were promising (Juengel et al. 2002), blocking the binding of these proteins to the BMPR1B receptor using antibodies directed against the extracellular domain did not show consistent effects on ovulation rate ( $L$ Juengel \& K P McNatty, unpublished results). Thus, subsequent studies were focused on immunization strategies against GDF9 and BMP15.

Three possible outcomes were examined with the immunization strategies: i) cessation of reproductive cycles; ii) increased ovulation rate during a natural cycle and iii) increased responsiveness to a superovulation regimen. Considerable progress has been made in using active immunization to stop reproductive cycles and increase ovulation rate; however, the third option remains elusive. Peptide mapping identified the $\mathrm{N}$-terminal of the mature polypeptides as the most efficacious in generating high-titre antibodies capable of 
specific neutralization of either GDF9 or BMP15 (Juengel et al. 2002, McNatty et al. 2007). Furthermore, through the use of different adjuvants (oil based or water based), the amount of GDF9 or BMP15 able to be neutralized could be modulated to either cause cessation of reproductive cycles (Juengel et al. 2002, McNatty et al. 2007) or increased ovulation rate (Juengel et al. 2004a). Immunization using a water-based adjuvant did not negatively affect embryo survival, although the animal numbers in that study were not large enough to observe subtle differences (Juengel et al. 2004a). Initial studies indicated that the increased ovulation rate observed in BMP15-immunized animals could result in an increased lambing rate (Juengel et al. 2004a). However, preliminary analysis from ewes immunized annually over a 3-year trial period has shown that, while increased ovulation rates were observed, the lambing rates in BMP15-immunized ewes became increasingly unfavourable over time (increased non-pregnant ewes and ewes with three or more lambs) when compared with the commercially available twinning vaccines utilizing an androstenedione-based antigen (Juengel et al. 2011b).

All attempts to increase the superovulation rate response to exogenous FSH through immunization against either BMP15 or GDF9 have proven unsuccessful (J L Juengel \& K P McNatty, unpublished results, Juengel et al. 2011a). For BMP15-immunized ewes, the ovarian follicular populations have been studied to determine why immunized ewes do not show an increased responsiveness to exogenous gonadotrophins (Juengel et al. 2011a). While the follicles from BMP15 ewes were smaller in diameter with fewer granulosa cells than control ewes, their responsiveness to gonadotrophins did not mimic what was observed in the Inverdale animal. Although the follicles tended to be more responsive to human chorionic gonadotrophin (hCG, used to measure $\mathrm{LH}$ responsiveness), the basal cAMP production was also elevated. Thus, the follicles may have been prematurely luteinizing, thereby preventing increased responsiveness to exogenous gonadotrophins. However, this possibility could not have interfered with the increased ovulation rate in natural (i.e. not stimulated with gonadotrophins) cycles (Juengel et al. 2004a). While attempts to improve the efficacy of current superovulation regimens have not been successful, individual animals undergoing natural reproductive cycles were noted with very high ovulation rates $(>10)$. The current working hypothesis is that ovulation rate increases in response to decreasing amounts of biologically active BMP15 or GDF9 until a critical low threshold is reached, at which follicular growth ceases (McNatty et al. 2004). Thus, immunization strategies to reduce the amount of BMP15 and/or GDF9 to levels just above the critical threshold could form the basis of new superovulation protocols not involving exogenous FSH.

Immunization against BMP15 and GDF9 has also been examined in cattle. Preliminary studies showed responses that were similar, although not identical, to sheep when examining the effects during the oestrous cycle, with some animals progressing towards anovulation whereas others experienced high ovulation rates (Juengel et al. 2007, 2009). The results in cattle indicated quite clearly that GDF9 and BMP15 proteins are involved in the regulation of follicular growth and/or ovulation rate. However, there were practical difficulties in controlling these effects. These were due to the variability of responses experienced as well as the difficulty in inducing an appropriately high humoral immune response (Juengel et al. 2009).

\section{Effects of mutations in genes controlling ovulation rate on embryo/fetal survival, lamb birth weight, lamb survival and lamb growth}

The relationships between ovulation rate and embryo/ fetal survival, lamb birth weight, lamb survival and lamb growth are complex. As ovulation rate increases, the individual chance of any one ova developing into a lamb decreases (Hanrahan 1982). Likewise, increased litter size is related to decreased birth weights, and small birth weights are linked to higher lamb mortality and lower lamb growth rates (Morris et al. 2003, Kerslake et al. 2005, Peterson et al. 2006). When these parameters were examined in ewes with altered BMP15 bioactivity, the aforementioned relationships appeared similar. In Inverdale ewes (Davis et al. 1993, Demmers et al. 2011), embryo/fetus survival or lamb performance was not altered and immunization against BMP15 also did not appear to alter these factors either if changes in ovulation rate/litter size were accounted for (Juengel et al. 2004a, 2011b). Little data are available regarding the effects of mutations in the GDF9 gene on these factors (Juengel et al. 2004a, Nicol et al. 2009), but given that GDF9 and BMP15 seem to act cooperatively in sheep, it seems likely that mutations in GDF9 would also not affect these relationships.

The picture is more complex in Booroola animals. Given that BMPR1B is expressed throughout the body (Wilson et al. 2001), in contrast to the limited expression of BMP15 and GDF9 in the oocyte, some effect of the mutation in BMPR1B on lamb performance independent of ovulation rate changes could be postulated. In one study, while birth weight and growth were similar between non-carriers and heterozygous carriers of the $B M P R 1 B$ mutation, homozygous carriers were smaller at birth, had reduced post-weaning growth rates and lower mature body weights (Gootwine et al. 2006). Other studies have shown that birth weight, growth and 12 -month body weight were affected in both the heterozygous and the homozygous carriers (Kumar et al. 2008). However, Willingham et al. (2002) did not find an effect on birth weight or growth rate in Booroola wethers that was independent of litter size at birth/ 
rearing. Similarly, Kleemann et al. (1985) concluded that the Booroola gene did not appear to affect growth or carcass characteristics. Genotype did not appear to affect lamb survival (Gootwine et al. 2008). Taken together, it seems most likely that changes in ovulation rate, and thus litter size at birth and during rearing, are the major influences on lamb performance in Booroola ewes with the potential for more subtle effects on these factors occurring independently of changes in litter size.

\section{The relevance of sheep lines with mutations in single genes to understanding ovarian function}

As stated earlier, both GDF9 and BMP15 have been shown to be essential for ovarian follicular development in sheep, whereas in mice, GDF9, but not BMP15, is essential. This suggests that the actions of these proteins may differ between species. Naturally occurring mutations of both BMP15 and GDF9 have been identified in humans and those in BMP15 that result in a loss of biologically active protein lead to premature ovarian failure (Di Pasquale et al. 2004, 2006, Dixit et al. 2006). Mutations in GDF9 were also linked with sterility (Dixit et al. 2005, Laissue et al. 2006) and dizygotic twinning (Palmer et al. 2006) similar to what has been observed in sheep. While variation in BMP15 was not found to be a major underlying cause of dizygotic twinning in humans, three rare mutations were observed in mothers of spontaneous dizygotic twins (MODZT) but not in controls. However, association between these mutations and twinning could not be established (Zhao et al. 2008). Similarly, while mutations in BMPR1B were observed in MODZT, they were only marginally associated with increased twinning (Luong et al. 2011). Similar to the increased responsiveness to gonadotrophins observed in sheep heterozygous for a BMP15 mutation or homozygous for the BMPR1B mutation (McNatty et al. 2006a), mutations in the human population in BMP15 have also been linked weakly to a higher response to FSH (Moron et al. 2006, Hanevik et al. 2011). In addition, the expression patterns for BMP15 and GDF9, as well as their receptors, are similar between sheep and humans (Juengel \& McNatty 2005). Thus, in general terms, the actions of GDF9 and BMP15 appear similar between sheep and humans providing evidence that understanding the role of these proteins in the sheep model is not only important for regulating reproductive efficiency in sheep but also for providing insights into control of ovarian follicular development in humans.

Studies examining the functions of BMP15 and GDF9 in vitro also support the relevance of the sheep models in understanding control of ovarian follicular development in multiple species. Generally, GDF9 and BMP15 (alone or combined) stimulate granulosa cell proliferation, inhibit progesterone production and stimulate inhibin production in both sheep and human granulosa cells
(Juengel \& McNatty 2005). While GDF9 and BMP15 have some activity on their own, both human and ovine GDF9 and BMP15 together have been shown to work synergistically (McNatty et al. 2005c, Peng et al. 2013). Taken together with the similarity in expression patterns of GDF9 and BMP15 in the oocytes of growing follicles in both humans and sheep, it is most likely that in sheep and humans, GDF9 and BMP15 work as a functional unit (Juengel \& McNatty 2005, Peng et al. 2013).

Other factors regulating cellular response to ligands are expression of the receptors for the ligands and which cellular signalling pathways are activated on ligand binding. Members of the TGFB superfamily typically interact with a receptor complex composed of two types (type 1 and 2) of membrane-bound serine-threonine kinases (de Caestecker 2004, ten Dijke \& Hill 2004). Both GDF9 and BMP15 use BMPR2 for the type 2 receptor (Vitt et al. 2002, Moore et al. 2003, Edwards et al. 2008). BMP15 signals through BMPR1B as its type 1 receptor (Moore et al. 2003, Pulkki et al. 2012) with GDF9 signalling through the TGFBR1 receptor (Mazerbourg et al. 2004). ACVR1B has been proposed to be possibly involved in signalling when both BMP15 and GDF9 are present (Peng et al. 2013). The classical signalling pathway used by these receptors is the SMAD signalling pathway with two receptor-associated subfamilies (Miyazawa et al. 2002, ten Dijke \& Hill 2004). Interestingly, BMPR1B activates the classical BMP subfamily pathway (Smad 1/5/8) whereas TGFBR1 activates a classical activin/TGFB subfamily pathway (Smad 2/3). Thus, the pairing of BMPR2 with TGFBR1 for GDF9 signalling is an unusual pairing. Other nonclassical pathways such as MAP kinases and NF- $\kappa B$ may also be involved in GDF9 and BMP15 signalling (Moore et al. 2003, Reader et al. 2011).

Recently, activation of cellular signalling pathways in rat granulosa cells following treatment with a GDF9 and BMP15 combination (GDF9+BMP15) was shown to differ depending on whether the GDF9 and BMP15 were derived from ovine or murine sequence (Reader et al. 2011). While the classical Smad $2 / 3$ pathways were shown to be critical for granulosa cell proliferation for both mouse and ovine GDF9+BMP15, non-classical

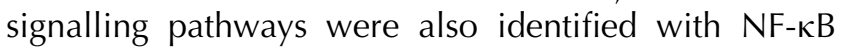
being critical for activity of ovine, but not mouse, protein. Similarly, inhibition of the ERK-MAPK pathway partially blocks activity of mouse, but not ovine, GDF9+BMP15. Activation of the Smad 2/3 pathway was also shown to be involved in the regulation of expression of genes involved in cumulus cell expansion by human GDF9+BMP15 (Peng et al. 2013). No evidence for the role of NF- $\kappa B$ was observed when studying the combined actions of mouse GDF9 and human BMP15 (Mottershead et al. 2012); however, signalling through NF- $\kappa \mathrm{B}$ was linked to the species of origin of GDF9 (Reader et al. 2011). Preliminary studies carried out in our laboratory also identified Smad 2/3 as a classical signalling pathway and 
NF- $\kappa B$ and JNK as non-classical signalling pathways potentially involved in stimulation of rat granulosa cell proliferation by human GDF9+BMP15, indicating similarity between the human and ovine proteins.

There is still considerable knowledge to be gained regarding the regulation and function of BMP15 and GDF9. These include, but are not limited to, a better understanding of the biologically active forms of BMP15 and GDF9 produced by the oocyte in vivo. Analysis of GDF9 and BMP15, in follicular fluid, oocyte lysates and from cell lines expressing GDF9 or BMP15, indicates that GDF9 and BMP15 may be secreted as a complex mix of forms (Liao et al. 2003, 2004, McNatty et al. 2006b, Edwards et al. 2008, McIntosh et al. 2008, Lin et al. 2012). New data are emerging regarding the effects of post-translational modifications on the activity of GDF9 and BMP15 (McMahon et al. 2008) and the role of sequence in the proregion in regulating activity of the mature region. These may operate via control of processing of the protein and regulating latency of the mature protein or potentially direct actions (McIntosh et al. 2008, 2012, Tibaldi et al. 2010, Simpson et al. 2012, Al-Musawi et al. 2013). The relative importance of the effects of GDF9 and BMP15 on mural vs cumulus granulosa cell function is also unclear, and sometimes debated. Being produced by the oocyte, the cumulus cells are clearly exposed to high concentrations of these growth factors and their role in regulating cumulus cell function and oocyte quality has been shown (Gilchrist et al. 2008, Gilchrist 2011). However, the presence of these factors in follicular fluid and the ability of passive immunization against BMP15 to affect ovulation rate demonstrate an essential role at the level of the mural granulosa cells also (Juengel et al. 2002). Understanding these and other factors better will be essential to fully understand the role of GDF9 and BMP15 in regulating follicular development.

Thus, while there is still much to learn regarding the actions of BMP15 and GDF9, the sheep models have proven invaluable in understanding how the oocytederived growth factors regulate ovarian follicular development, ovulation rate and oocyte function. While the knock-out Gdf9 mouse (Dong et al. 1996) clearly set us on the track of understanding the essential role of these growth factors in regulating female fertility, it could be argued that the less well-known Hanna sheep line, which is in essence a naturally occurring sheep knock-out of $B M P 15$, together with the Inverdale line, provided the first unequivocal evidence for the essential role of BMP15 in regulating female fertility (Galloway et al. 2000). The discovery that GDF9 was also essential for ovarian follicular development and regulating ovulation rate in sheep (Juengel et al. 2002, Hanrahan et al. 2004) shortly thereafter set us on the track to determine how the two oocyte-derived growth factors work together to control fertility.

\section{Declaration of interest}

AgResearch holds patents related to the use of BMP15 and GDF9 in regulating ovarian function. J L Juengel, G $\mathrm{H}$ Davis and K P McNatty are listed as inventors on these patents; however, all have assigned their ownership to AgResearch Ltd.

\section{Funding}

This work was funded by the New Zealand Foundation for Research, Science and Technology (now Ministry for Business, Innovation and Employment) contract C10X0810 and by AgResearch Core Funding.

\section{References}

Al-Musawi SL, Walton KL, Heath D, Simpson CM \& Harrison CA 2013 Species differences in the expression and activity of bone morphogenetic protein 15. Endocrinology 154 888-899. (doi:10.1210/en.2012-2015)

Bodin L, Di Pasquale E, Fabre S, Bontoux M, Monget P, Persani L \& Mulsant P 2007 A novel mutation in the bone morphogenetic protein 15 gene causing defective protein secretion is associated with both increased ovulation rate and sterility in Lacaune sheep. Endocrinology 148 393-400. (doi:10.1210/en.2006-0764)

Braw-Tal R, McNatty KP, Smith P, Heath DA, Hudson NL, Phillips DJ, McLeod BJ \& Davis GH 1993 Ovaries of ewes homozygous for the $\mathrm{X}$-linked Inverdale gene (FecXI) are devoid of secondary and tertiary follicles but contain many abnormal structures. Biology of Reproduction 49 895-907. (doi:10.1095/biolreprod49.5.895)

de Caestecker M 2004 The transforming growth factor- $\beta$ superfamily of receptors. Cytokine \& Growth Factor Reviews 15 1-11. (doi:10.1016/ j.cytogfr.2003.10.004)

Campbell BK, Baird DT, Souza CJ \& Webb R 2003 The FecB (Booroola) gene acts at the ovary: in vivo evidence. Reproduction 126 101-111. (doi:10.1530/rep.0.1260101)

Campbell BK, Souza CJ, Skinner AJ, Webb R \& Baird DT 2006 Enhanced response of granulosa and theca cells from sheep carriers of the FecB mutation in vitro to gonadotropins and bone morphogenic protein-2, -4 , and -6. Endocrinology 147 1608-1620. (doi:10.1210/en.2005-0604)

Chu MX, Li BX, Wang JY, Ye SC \& Fang L 2004 Association between PCRSSCP of growth differentiation factor 9 gene and high prolificacy in Small Tail Han sheep. Animal Biotechnology 15 111-120. (doi:10.1081/ABIO200032582)

Chu MX, Liu ZH, Jiao CL, He YQ, Fang L, Ye SC, Chen GH \& Wang JY 2007 Mutations in BMPR-IB and BMP-15 genes are associated with litter size in Small Tailed Han sheep (Ovis aries). Journal of Animal Science $\mathbf{8 5}$ 598-603. (doi:10.2527/jas.2006-324)

Crawford JL \& McNatty KP 2012 The ratio of growth differentiation factor 9:bone morphogenetic protein 15 mRNA expression is tightly co-regulated and differs between species over a wide range of ovulation rates. Molecular and Cellular Endocrinology 348 339-343. (doi:10.1016/ j.mce.2011.09.033)

Crawford JL, Heath DA, Reader KL, Quirke LD, Hudson NL, Juengel JL \& McNatty KP 2011 Oocytes in sheep homozygous for a mutation in bone morphogenetic protein receptor $1 \mathrm{~B}$ express lower mRNA levels of bone morphogenetic protein 15 but not growth differentiation factor 9 . Reproduction 142 53-61. (doi:10.1530/REP-10-0485)

Davis GH 2004 Fecundity genes in sheep. Animal Reproduction Science 82-83 247-253. (doi:10.1016/j.anireprosci.2004.04.001)

Davis GH, McEwan JC, Fennessy PF, Dodds KG, McNatty KP \& O WS 1992 Infertility due to bilateral ovarian hypoplasia in sheep homozygous (FecXI FecXI) for the Inverdale prolificacy gene located on the $\mathrm{X}$ chromosome. Biology of Reproduction 46 636-640. (doi:10.1095/ biolreprod46.4.636)

Davis GH, Dodds KG, McEwan JC \& Fennessy PF 1993 Liveweight, fleece weight and prolificacy of Romney ewes carrying the Inverdale prolificacy gene (Fexl) located on the X-chromosome. Livestock Production Science 34 83-91. (doi:10.1016/0301-6226(93)90037-I) 
Davis GH, Dodds KG \& Bruce GD 1999 Combined effect of the Inverdale and Booroola prolificacy genes on ovulation rate in sheep. Proceedings of the Association for the Advancement of Animal Breeding and Genetics 13 74-77.

Davis GH, Dodds KG, Wheeler R \& Jay NP 2001 Evidence that an imprinted gene on the $X$ chromosome increases ovulation rate in sheep. Biology of Reproduction 64 216-221. (doi:10.1095/biolreprod64.1.216)

Davis GH, Galloway SM, Ross IK, Gregan SM, Ward J, Nimbkar BV, Ghalsasi PM, Nimbkar C, Gray GD, Subandriyo et al. 2002 DNA tests in prolific sheep from eight countries provide new evidence on origin of the Booroola (FecB) mutation. Biology of Reproduction 66 1869-1874. (doi:10.1095/biolreprod66.6.1869)

Davis GH, Farquhar PA, O'Connell AR, Everett-Hincks JM, Wishart PJ, Galloway SM \& Dodds KG 2006a A putative autosomal gene increasing ovulation rate in Romney sheep. Animal Reproduction Science 92 65-73. (doi:10.1016/j.anireprosci.2005.05.015)

Davis GH, Balakrishnan L, Ross IK, Wilson T, Galloway SM, Lumsden BM, Hanrahan JP, Mullen M, Mao XZ, Wang GL et al. 2006b Investigation of the Booroola (FecB) and Inverdale (FecX(I)) mutations in 21 prolific breeds and strains of sheep sampled in 13 countries. Animal Reproduction Science 92 87-96. (doi:10.1016/j.anireprosci.2005.06.001)

Davis GH, Galloway SM, O'Connell A, Farquhar PA, McNatty KP \& Juengel JL 2008 Hyper-prolific ewes carrying copies of three major genes: a model for studying genes controlling ovulation rate. Biology of Reproduction $\mathbf{7 8} 110$ abstract 244.

Demars J, Fabre S, Sarry J, Rossetti R, Persani L, Tosser-Klopp G, Mulsant P, Nowak R, Drobik W, Martyniuk E et al. 2012 Two novel mutations in the bone morphogenetic protein 15 gene are associated with increased ovulation rate, but no sterility, in the French Grivette and the Polish Olkuska breeds of sheep. Reproduction in Domestic Animals 47505 abstract 1710

Demmers KJ, Smaill B, Davis GH, Dodds KG \& Juengel JL 2011 Heterozygous Inverdale ewes show increased ovulation rate sensitivity to pre-mating nutrition. Reproduction, Fertility, and Development $\mathbf{2 3}$ 866-875. (doi:10.1071/RD10344)

ten Dijke P \& Hill CS 2004 New insights into TGF- $\beta$-Smad signalling. Trends in Biochemical Sciences 29 265-273. (doi:10.1016/j.tibs.2004. 03.008)

Di Pasquale E, Beck-Peccoz P \& Persani L 2004 Hypergonadotropic ovarian failure associated with an inherited mutation of human bone morphogenetic protein-15 (BMP15) gene. American Journal of Human Genetics 75 106-111. (doi:10.1086/422103)

Di Pasquale E, Rossetti R, Marozzi A, Bodega B, Borgato S, Cavallo L, Einaudi S, Radetti G, Russo G, Sacco M et al. 2006 Identification of new variants of human BMP15 gene in a large cohort of women with premature ovarian failure. Journal of Clinical Endocrinology and Metabolism 91 1976-1979. (doi:10.1210/jc.2005-2650)

Dixit H, Rao LK, Padmalatha V, Kanakavalli M, Deenadayal M, Gupta N, Chakravarty B \& Singh L 2005 Mutational screening of the coding region of growth differentiation factor 9 gene in Indian women with ovarian failure. Menopause 12 749-754. (doi:10.1097/01.gme.0000184424. 96437.7a)

Dixit H, Rao LK, Padmalatha VV, Kanakavalli M, Deenadayal M, Gupta N, Chakrabarty B \& Singh L 2006 Missense mutations in the BMP15 gene are associated with ovarian failure. Human Genetics 119 408-415. (doi:10.1007/s00439-006-0150-0)

Dong J, Albertini DF, Nishimori K, Kumar TR, Lu N \& Matzuk MM 1996 Growth differentiation factor-9 is required during early ovarian folliculogenesis [see comments]. Nature 383 531-535. (doi:10.1038/ 383531a0)

Drouilhet L, Lecerf F, Bodin L, Fabre S \& Mulsant P 2009 Fine mapping of the FecL locus influencing prolificacy in Lacaune sheep. Animal Genetics 40 804-812. (doi:10.1111/j.1365-2052.2009.01919.x)

Drouilhet L, Taragnat C, Fontaine J, Duittoz A, Mulsant P, Bodin L \& Fabre S 2010 Endocrine characterization of the reproductive axis in highly prolific lacaune sheep homozygous for the FecLL mutation. Biology of Reproduction 82 815-824. (doi:10.1095/biolreprod.109.082065)

Dufour JJ, Cognie Y, Mermillod P, Mariana JC \& Romain RF 2000 Effects of the Booroola Fec gene on ovarian follicular populations in superovulated Romanov ewes pretreated with a GnRH antagonist. Journal of Reproduction and Fertility 118 85-94. (doi:10.1530/reprod/118.1.85)
Edwards SJ, Reader KL, Lun S, Western A, Lawrence S, McNatty KP \& Juengel JL 2008 The cooperative effect of growth and differentiation factor-9 and bone morphogenetic protein (BMP)-15 on granulosa cell function is modulated primarily through BMP receptor II. Endocrinology 149 1026-1030. (doi:10.1210/en.2007-1328)

Edwards SJ, Martin S, Ross I \& Juengel JL 2009 The Booroola mutation in ALK6 does not affect ligand-induced signalling. Queenstown Molecular Biology Meetings - Reproductive Biology Meeting, Queenstown, New Zealand.

Fabre S, Pierre A, Pisselet C, Mulsant P, Lecerf F, Pohl J, Monget P \& Monniaux D 2003 The Booroola mutation in sheep is associated with an alteration of the bone morphogenetic protein receptor-IB functionality. Journal of Endocrinology 177 435-444. (doi:10.1677/joe.0. 1770435)

Fabre S, Pierre A, Mulsant P, Bodin L, Di Pasquale E, Persani L, Monget P \& Monniaux D 2006 Regulation of ovulation rate in mammals: contribution of sheep genetic models. Reproductive Biology and Endocrinology 4 20. (doi:10.1186/1477-7827-4-20)

Feary ES, Juengel JL, Smith P, French MC, $\mathrm{O}^{\prime}$ Connell AR, Lawrence SB, Galloway SM, Davis GH \& McNatty KP 2007 Patterns of expression of messenger RNAs encoding GDF9, BMP15, TGFBR1, BMPR1B, and BMPR2 during follicular development and characterization of ovarian follicular populations in ewes carrying the Woodlands FecX2W mutation. Biology of Reproduction 77 990-998. (doi:10.1095/biolreprod.107.062752)

Galloway SM, McNatty KP, Cambridge LM, Laitinen MP, Juengel JL, Jokiranta TS, McLaren RJ, Luiro K, Dodds KG, Montgomery GW et al. 2000 Mutations in an oocyte-derived growth factor gene (BMP15) cause increased ovulation rate and infertility in a dosage-sensitive manner. Nature Genetics 25 279-283. (doi:10.1038/77033)

Gilchrist RB 2011 Recent insights into oocyte-follicle cell interactions provide opportunities for the development of new approaches to in vitro maturation. Reproduction, Fertility, and Development 23 23-31. (doi:10.1071/RD10225)

Gilchrist RB, Lane M \& Thompson JG 2008 Oocyte-secreted factors: regulators of cumulus cell function and oocyte quality. Human Reproduction Update 14 159-177. (doi:10.1093/humupd/dmm040)

Gootwine E, Rozov A, Bor A \& Reicher S 2006 Carrying the FecB (Booroola) mutation is associated with lower birth weight and slower post-weaning growth rate for lambs, as well as a lighter mature bodyweight for ewes. Reproduction, Fertility, and Development 18 433-437. (doi:10.1071/ RD05134)

Gootwine E, Reicher S \& Rozov A 2008 Prolificacy and lamb survival at birth in Awassi and Assaf sheep carrying the FecB (Booroola) mutation. Animal Reproduction Science 108 402-411. (doi:10.1016/j.anireprosci. 2007.09.009)

Hanevik HI, Hilmarsen HT, Skjelbred CF, Tanbo T \& Kahn JA 2011 A single nucleotide polymorphism in BMP15 is associated with high response to ovarian stimulation. Reproductive Biomedicine Online 23 97-104. (doi:10.1016/j.rbmo.2011.02.015)

Hanrahan JP 1982 Selection for increased ovulation rate, litter size and embryo survival. In 2nd World Congress on Genetics Applied to Livestock Production, vol 5, pp 294-309.

Hanrahan JP, Gregan SM, Mulsant P, Mullen M, Davis GH, Powell R \& Galloway SM 2004 Mutations in the genes for oocyte-derived growth factors GDF9 and BMP15 are associated with both increased ovulation rate and sterility in Cambridge and Belclare sheep (Ovis aries). Biology of Reproduction 70 900-909. (doi:10.1095/biolreprod.103.023093)

Hayashi K, O'Connell AR, Juengel JL, McNatty KP, Davis GH, Bazer FW \& Spencer TE 2008 Postnatal uterine development in Inverdale ewe lambs. Reproduction 135 357-365. (doi:10.1530/REP-07-0323)

Ho CC \& Bernard DJ 2009 Bone morphogenetic protein 2 signals via BMPR1A to regulate murine follicle-stimulating hormone $\beta$ subunit transcription. Biology of Reproduction 81 133-141. (doi:10.1095/ biolreprod.108.074211)

Hussein TS, Thompson JG \& Gilchrist RB 2006 Oocyte-secreted factors enhance oocyte developmental competence. Developmental Biology 296 514-521. (doi:10.1016/j.ydbio.2006.06.026)

Juengel JL \& McNatty KP 2005 The role of proteins of the transforming growth factor- $\beta$ superfamily in the intraovarian regulation of follicular development. Human Reproduction Update 11 143-160. (doi:10.1093/ humupd/dmh061) 
Juengel JL, Quirke LD, Tisdall DJ, Smith P, Hudson NL \& McNatty KP 2000 Gene expression in abnormal ovarian structures of ewes homozygous for the Inverdale prolificacy gene. Biology of Reproduction 62 1467-1478. (doi:10.1095/biolreprod62.6.1467)

Juengel JL, Hudson NL, Heath DA, Smith P, Reader KL, Lawrence SB, O'Connell AR, Laitinen MP, Cranfield M, Groome NP et al. 2002 Growth differentiation factor 9 and bone morphogenetic protein 15 are essential for ovarian follicular development in sheep. Biology of Reproduction 67 1777-1789. (doi:10.1095/biolreprod.102.007146)

Juengel JL, Hudson NL, Whiting L \& McNatty KP 2004a Effects of immunization against bone morphogenetic protein 15 and growth differentiation factor 9 on ovulation rate, fertilization, and pregnancy in ewes. Biology of Reproduction 70 557-561. (doi:10.1095/biolreprod. 103.023333)

Juengel JL, Bodensteiner KJ, Heath DA, Hudson NL, Moeller CL, Smith P, Galloway SM, Davis GH, Sawyer HR \& McNatty KP 2004b Physiology of GDF9 and BMP15 signalling molecules. Animal Reproduction Science 82-83 447-460. (doi:10.1016/j.anireprosci.2004.04.021)

Juengel JL, McNatty KP, Moore LG \& Bower RS 2005 Modulation of ovulation. International Patent Application No PCT/NZ2005/000314.

Juengel JL, Reader KL, Bibby AH, Lun S, Ross I, Haydon LJ \& McNatty KP 2006 The role of bone morphogenetic proteins 2, 4, 6 and 7 during ovarian follicular development in sheep: contrast to rat. Reproduction 131 501-513. (doi:10.1530/rep.1.00958)

Juengel JL, Hudson N, Hamel K, Berg M \& McNatty KP 2007 Both growth differentiation factor 9 (GDF9) and bone morphogenetic protein 15 (BMP15) regulate ovulation rate in cattle. Biology of Reproduction 77150.

Juengel JL, Proctor LE, Farquhar PA \& Davis GH 2008 Association among ovulation rate, serum concentrations of $\mathrm{FSH}$, response to exogenous FSH and fertility in ewes heterozygous for the Booroola gene ( $\mathrm{FecB})$. Reproduction in Domestic Animals 43 (Suppl 3) 79 abstract.

Juengel JL, Hudson NL, Berg M, Hamel K, Smith P, Lawrence SB, Whiting L \& McNatty KP 2009 Effects of active immunization against growth differentiation factor 9 and/or bone morphogenetic protein 15 on ovarian function in cattle. Reproduction 138 107-114. (doi:10.1530/REP09-0009)

Juengel JL, Quirke LD, Lun S, Heath DA, Johnstone PD \& McNatty KP 2011 a Effects of immunizing ewes against bone morphogenetic protein 15 on their responses to exogenous gonadotrophins to induce multiple ovulations. Reproduction 142 565-572. (doi:10.1530/REP-11-0126)

Juengel JL, Proctor L, Wearne K, Olliver D, Hudson N, Jensen D, Davis GH, Johnstone P \& McNatty K 2011b Effects of immunization against androstenedione or bone morphogenetic protein 15 (BMP15) on reproductive performance in sheep. Reproduction in Domestic Animals 46115 abstract P130.

Juengel JL, $\mathrm{O}^{\prime}$ Connell AR, French MC, Proctor LE, Wheeler R, Farquhar PA, Dodds KG, Galloway SM, Johnstone PD \& Davis GH 2011c Identification of a line of sheep carrying a putative autosomal gene increasing ovulation rate in sheep that does not appear to interact with mutations in the transforming growth factor $\beta$ superfamily. Biology of Reproduction 85 113-120. (doi:10.1095/biolreprod.110.090514)

Kerslake JI, Everett-Hincks JM \& Campbell A 2005 Lamb survival: a new examination of an old problem. Proceedings of the New Zealand Society for Animal Production 65 13-18.

Kleemann DO, Ponzoni RW, Stafford JE, Cutten IN \& Grimson RJ 1985 Growth and carcass characters of the South Australian Merino and its crosses with the Booroola and Trangie Fertility Merino. Australian Journal of Experimental Agriculture 25 750-757. (doi:10.1071/ EA9850750)

Kumar S, Mishra AK, Kolte AP, Arora AL, Singh D \& Singh VK 2008 Effects of the Booroola $(\mathrm{FeCB})$ genotypes on growth performance, ewe's productivity efficiency and litter size in Garole x Malpura sheep. Animal Reproduction Science 105 319-331. (doi:10.1016/j.anireprosci.2007. 03.012)

Lahoz B, Alabart JL, Jurado JJ, Calvo JH, Martinez-Royo A, Fantova E \& Folch J 2011 Effect of the $\operatorname{FecX}(\mathrm{R})$ polymorphism in the bone morphogenetic protein 15 gene on natural or equine chorionic gonadotropin-induced ovulation rate and litter size in Rasa Aragonesa ewes and implications for on-farm application. Journal of Animal Science 89 3522-3530. (doi:10.2527/jas.2010-3828)
Laissue P, Christin-Maitre S, Touraine P, Kuttenn F, Ritvos O, Aittomaki K, Bourcigaux N, Jacquesson L, Bouchard P, Frydman R et al. 2006 Mutations and sequence variants in GDF9 and BMP15 in patients with premature ovarian failure. European Journal of Endocrinology 154 739-744. (doi:10.1530/eje.1.02135)

Liao WX, Moore RK, Otsuka F \& Shimasaki S 2003 Effect of intracellular interactions on the processing and secretion of bone morphogenetic protein-15 (BMP-15) and growth and differentiation factor-9: implication of the aberrant ovarian phenotype of BMP-15 mutant sheep. Journal of Biological Chemistry 278 3713-3719. (doi:10.1074/jbc.M210598200)

Liao WX, Moore RK \& Shimasaki S 2004 Functional and molecular characterization of naturally occurring mutations in the oocyte-secreted factors bone morphogenetic protein-15 and growth and differentiation factor-9. Journal of Biological Chemistry 279 17391-17396. (doi:10.1074/ jbc.M401050200)

Lin JY, Pitman J, Bibby AH, Hudson NL, McIntosh CJ, Juengel JL \& McNatty KP 2012 Effects of species differences on oocyte regulation of granulosa cell function. Reproduction 144 557-567. (doi:10.1530/REP12-0267)

Luong HT, Chaplin J, McRae AF, Medland SE, Willemsen G, Nyholt DR, Henders AK, Hoekstra C, Duffy DL, Martin NG et al. 2011 Variation in BMPR1B, TGFRB1 and BMPR2 and control of dizygotic twinning. Twin Research and Human Genetics 14 408-416. (doi:10.1375/twin.14.5. 408)

Mansanet C, Drouilhet L, Bardou P, Sary J, Tabet K, Bodin L, Mulsant P \& Fabre $\mathbf{S} 2012$ Identification of the FecL fecundity major gene controlling prolificacy in the Lacaune sheep breed. Reproduction in Domestic Animals 47 491-492. (doi:10.1111/j.1439-0531.2011.01909.x)

Martinez-Royo A, Jurado JJ, Smulders JP, Marti JI, Alabart JL, Roche A, Fantova E, Bodin L, Mulsant P, Serrano M et al. 2008 A deletion in the bone morphogenetic protein 15 gene causes sterility and increased prolificacy in Rasa Aragonesa sheep. Animal Genetics 39 294-297. (doi:10.1111/j.1365-2052.2008.01707.x)

Mazerbourg S, Klein C, Roh J, Kaivo-Oja N, Mottershead DG, Korchynskyi O, Ritvos O \& Hsueh AJ 2004 Growth differentiation factor-9 signaling is mediated by the type I receptor, activin receptor-like kinase 5. Molecular Endocrinology 18 653-665. (doi:10.1210/me.20030393)

McIntosh CJ, Lun S, Lawrence S, Western AH, McNatty KP \& Juengel JL 2008 The proregion of mouse BMP15 regulates the cooperative interactions of BMP15 and GDF9. Biology of Reproduction 79 889-896. (doi:10.1095/biolreprod.108.068163)

McIntosh CJ, Lawrence S, Smith P, Juengel JL \& McNatty KP 2012 Active immunization against the proregions of GDF9 or BMP15 alters ovulation rate and litter size in mice. Reproduction 143 195-201. (doi:10.1530/ REP-11-0336)

McLeod BJ, Kyle SE, Ramsay MR \& Manley TR 1995 Hormone secretion patterns associated with increased ovulation rates or with ovarian dysfunction in Inverdale ( $\left.F e c X^{1}\right)$ ewes. Proceedings of the New Zealand Society for Animal Production 55 304-330.

McMahon HE, Sharma S \& Shimasaki S 2008 Phosphorylation of bone morphogenetic protein-15 and growth and differentiation factor-9 plays a critical role in determining agonistic or antagonistic functions. Endocrinology 149 812-817. (doi:10.1210/en.2007-1439)

McNatty KP, Henderson KM, Lun S, Heath DA, Ball K, Hudson NL, Fannin J, Gibb M, Kieboom LE \& Smith P 1985 Ovarian activity in Booroola X Romney ewes which have a major gene influencing their ovulation rate. Journal of Reproduction and Fertility 73 109-120. (doi:10.1530/jrf.0.0730109)

McNatty KP, Moore LG, Hudson NL, Quirke LD, Lawrence SB, Reader K, Hanrahan JP, Smith P, Groome NP, Laitinen M et al. 2004 The oocyte and its role in regulating ovulation rate: a new paradigm in reproductive biology. Reproduction 128 379-386. (doi:10.1530/rep.1.00280)

McNatty KP, Galloway SM, Wilson T, Smith P, Hudson NL, O'Connell A, Bibby AH, Heath DA, Davis GH, Hanrahan JP et al. 2005a Physiological effects of major genes affecting ovulation rate in sheep. Genetique, Selection, Evolution 37 (Suppl 1) S25-S38. (doi:10.1186/1297-968637-S1-S25)

McNatty KP, Juengel JL, Reader KL, Lun S, Myllymaa S, Lawrence SB, Western A, Meerasahib MF, Mottershead DG, Groome NP et al. 2005b 
Bone morphogenetic protein 15 and growth differentiation factor 9 co-operate to regulate granulosa cell function. Reproduction 129 473-480. (doi:10.1530/rep.1.0511)

McNatty KP, Juengel JL, Reader KL, Lun S, Myllymaa S, Lawrence SB, Western A, Meerasahib MF, Mottershead DG, Groome NP et al. $2005 \mathrm{C}$ Bone morphogenetic protein 15 and growth differentiation factor 9 co-operate to regulate granulosa cell function in ruminants. Reproduction 129 481-487. (doi:10.1530/rep.1.00517)

McNatty KP, Hudson N, Smith P \& Juengel JL 2006a The effects of superovulating sheep with mutations in either the activin-like kinase (Alk6) or bone morphogenetic protein (BMP15) genes on ovulation rate and embryo production. Journal of Reproduction and Development52 S39-S43.

McNatty KP, Lawrence S, Groome NP, Meerasahib MF, Hudson NL, Whiting L, Heath DA \& Juengel JL 2006 b Meat and Livestock Association Plenary Lecture 2005. Oocyte signalling molecules and their effects on reproduction in ruminants. Reproduction, Fertility, and Development 18 403-412. (doi:10.1071/RD05104)

McNatty KP, Hudson NL, Whiting L, Reader KL, Lun S, Western A, Heath DA, Smith P, Moore LG \& Juengel JL 2007 The effects of immunizing sheep with different BMP15 or GDF9 peptide sequences on ovarian follicular activity and ovulation rate. Biology of Reproduction 76 552-560. (doi:10.1095/biolreprod.106.054361)

McNatty KP, Heath DA, Hudson NL, Lun S, Juengel JL \& Moore LG 2009 Gonadotrophin-responsiveness of granulosa cells from bone morphogenetic protein 15 heterozygous mutant sheep. Reproduction 138 545-551. (doi:10.1530/REP-09-0154)

Miyazawa K, Shinozaki M, Hara T, Furuya T \& Miyazono K 2002 Two major Smad pathways in TGF- $\beta$ superfamily signalling. Genes to Cells 7 1191-1204. (doi:10.1046/j.1365-2443.2002.00599.x)

Monteagudo LV, Ponz R, Tejedor MT, Lavina A \& Sierra I 2009 A 17 bp deletion in the bone morphogenetic protein 15 (BMP15) gene is associated to increased prolificacy in the Rasa Aragonesa sheep breed. Animal Reproduction Science 110 139-146. (doi:10.1016/j.anireprosci.2008.01.005)

Moore RK, Otsuka F \& Shimasaki S 2003 Molecular basis of bone morphogenetic protein-15 signaling in granulosa cells. Journal of Biological Chemistry 278 304-310. (doi:10.1074/jbc.M207362200)

Moron FJ, de Castro F, Royo JL, Montoro L, Mira E, Saez ME, Real LM, Gonzalez A, Manes S \& Ruiz A 2006 Bone morphogenetic protein 15 (BMP15) alleles predict over-response to recombinant follicle stimulation hormone and iatrogenic ovarian hyperstimulation syndrome (OHSS). Pharmacogenetics and Genomics 16 485-495. (doi:10.1097/01.fpc. 0000215073.44589.96)

Morris S, Kenyon P, Burnham DL \& Everett-Hincks JM 2003 The effect of sward height on twin and triplet lamb birth weights and survival rates to weaning. Proceedings of the New Zealand Society for Animal Production 63 152-154.

Mottershead DG, Ritter LJ \& Gilchrist RB 2012 Signalling pathways mediating specific synergistic interactions between GDF9 and BMP15. Molecular Human Reproduction 18 121-128. (doi:10.1093/molehr/gar056)

Mulsant P, Lecerf F, Fabre S, Schibler L, Monget P, Lanneluc I, Pisselet C, Riquet J, Monniaux D, Callebaut I et al. 2001 Mutation in bone morphogenetic protein receptor-IB is associated with increased ovulation rate in Booroola Merino ewes. PNAS 98 5104-5109. (doi:10.1073/pnas. 091577598)

Nicol L, Bishop SC, Pong-Wong R, Bendixen C, Holm LE, Rhind SM \& McNeilly AS 2009 Homozygosity for a single base-pair mutation in the oocyte-specific GDF9 gene results in sterility in Thoka sheep. Reproduction 138 921-933. (doi:10.1530/REP-09-0193)

Otsuka F, McTavish KJ \& Shimasaki S 2011 Integral role of GDF-9 and BMP-15 in ovarian function. Molecular Reproduction and Development 78 9-21. (doi:10.1002/mrd.21265)

Palmer JS, Zhao ZZ, Hoekstra C, Hayward NK, Webb PM, Whiteman DC, Martin NG, Boomsma DI, Duffy DL \& Montgomery GW 2006 Novel variants in growth differentiation factor 9 in mothers of dizygotic twins. Journal of Clinical Endocrinology and Metabolism 91 4713-4716. (doi:10.1210/jc.2006-0970)

Paulini F \& Melo EO 2011 The role of oocyte-secreted factors GDF9 and BMP15 in follicular development and oogenesis. Reproduction in Domestic Animals 46 354-361. (doi:10.1111/j.1439-0531.2010. 01739.x)

Peng J, Li Q, Wigglesworth K, Rangarajan A, Kattamuri C, Peterson RT, Eppig JJ, Thompson TB \& Matzuk MM 2013 Growth differentiation factor 9:bone morphogenetic protein 15 heterodimers are potent regulators of ovarian functions. PNAS 110 E776-E785. (doi:10.1073/pnas. 1218020110)

Peterson SW, Kenyon P \& Morris S 2006 Do ewes with twin and triplet lambs produce different yields of milk and does the grazing behaviour of their lambs differ? Proceedings of the New Zealand Society for Animal Production 66 444-449.

Pulkki MM, Mottershead DG, Pasternack AH, Muggalla P, Ludlow $\mathbf{H}$, van Dinther $M$, Myllymaa $S$, Koli $K$, ten Dijke $P$, Laitinen $M$ et al. 2012 A covalently dimerized recombinant human bone morphogenetic protein-15 variant identifies bone morphogenetic protein receptor type $1 \mathrm{~B}$ as a key cell surface receptor on ovarian granulosa cells. Endocrinology 153 1509-1518. (doi:10.1210/en.2010-1390)

Reader KL, Heath DA, Lun S, McIntosh CJ, Western AH, Littlejohn RP, McNatty KP \& Juengel JL 2011 Signalling pathways involved in the cooperative effects of ovine and murine GDF9+BMP15-stimulated thymidine uptake by rat granulosa cells. Reproduction 142 123-131. (doi:10.1530/REP-10-0490)

Reader KL, Haydon LJ, Littlejohn RP, Juengel JL \& McNatty KP 2012 Booroola BMPR1B mutation alters early follicular development and oocyte ultrastructure in sheep. Reproduction, Fertility, and Development 24 353-361. (doi:10.1071/RD11095)

Ruoss C, Tadros A, O'Shea T, McFarlane J \& Almahbobi G 2009 Ovarian follicle development in Booroola sheep exhibiting impaired bone morphogenetic protein signalling pathway. Reproduction 138 689-696. (doi:10.1530/REP-09-0190)

Shackell GH, Hudson NL, Heath DA, Lun S, Shaw L, Condell L, Blay LR \& McNatty KP 1993 Plasma gonadotropin concentrations and ovarian characteristics in Inverdale ewes that are heterozygous for a major gene (FecX1) on the X chromosome that influences ovulation rate. Biology of Reproduction 48 1150-1156. (doi:10.1095/biolreprod48.5.1150)

Shimasaki S, Moore RK, Otsuka F \& Erickson GF 2004 The bone morphogenetic protein system in mammalian reproduction. Endocrine Reviews 25 72-101. (doi:10.1210/er.2003-0007)

Silva BD, Castro EA, Souza CJ, Paiva SR, Sartori R, Franco MM, Azevedo HC, Silva TA, Vieira AM, Neves JP et al. 2011 A new polymorphism in the growth and differentiation factor 9 (GDF9) gene is associated with increased ovulation rate and prolificacy in homozygous sheep. Animal Genetics 42 89-92. (doi:10.1111/j.1365-2052.2010.02078.x)

Simpson CM, Stanton PG, Walton KL, Chan KL, Ritter LJ, Gilchrist RB \& Harrison CA 2012 Activation of latent human GDF9 by a single residue change (Gly 391 Arg) in the mature domain. Endocrinology 153 1301-1310. (doi:10.1210/en.2011-1632)

Smith P, Braw-Tal R, Corrigan K, Hudson NL, Heath DA \& McNatty KP 1994 Ontogeny of ovarian follicle development in Booroola sheep fetuses that are homozygous carriers or non-carriers of the FecB gene. Journal of Reproduction and Fertility 100 485-490. (doi:10.1530/jrf.0.1000485)

Souza CJ, MacDougall C, Campbell BK, McNeilly AS \& Baird DT 2001 The Booroola (FecB) phenotype is associated with a mutation in the bone morphogenetic receptor type 1 B (BMPR1B) gene. Journal of Endocrinology 169 R1-R6. (doi:10.1677/joe.0.169R001)

Souza CJ, Campbell BK, McNeilly AS \& Baird DT 2003 Bone morphogenetic proteins and folliculogenesis: lessons from the Booroola mutation. Reproduction. Supplement 61 361-370.

Souza CJ, Gonzalez-Bulnes A, Campbell BK, McNeilly AS \& Baird DT 2004 Mechanisms of action of the principal prolific genes and their application to sheep production. Reproduction, Fertility, and Development 16 395-401. (doi:10.1071/RD04038)

Tibaldi E, Arrigoni G, Martinez HM, Inagaki K, Shimasaki S \& Pinna LA 2010 Golgi apparatus casein kinase phosphorylates bioactive Ser-6 of bone morphogenetic protein 15 and growth and differentiation factor 9 . FEBS Letters 584 801-805. (doi:10.1016/j.febslet.2009.12.052)

Vitt UA, Mazerbourg S, Klein C \& Hsueh AJ 2002 Bone morphogenetic protein receptor type II is a receptor for growth differentiation factor-9. Biology of Reproduction 67 473-480. (doi:10.1095/biolreprod67.2.473)

Willingham TD, Waldron DW \& Thompson PV 2002 Effect of the Fec ${ }^{B}$ allelle on birth weight and post-weaning production traits of RambouilletBooroola cross wethers. In Texas Agriculture Experiment Station Sheep and Goat, Wool and Mohair Research Reports, pp1-6. San Angelo, TX, USA: Texas A\&M University Agricultural Research and Extension Center. (available at: http://sanangelo.tamu.edu/files/2011/11/2002_1.pdf). 
Wilson T, Wu XY, Juengel JL, Ross IK, Lumsden JM, Lord EA, Dodds KG, Walling GA, McEwan JC, O'Connell AR et al. 2001 Highly prolific Booroola sheep have a mutation in the intracellular kinase domain of bone morphogenetic protein IB receptor (ALK-6) that is expressed in both oocytes and granulosa cells. Biology of Reproduction 64 1225-1235. (doi:10.1095/biolreprod64.4.1225)

Xu Y, Li E, Han Y, Chen L \& Xie Z 2010 Differential expression of mRNAs encoding BMP/Smad pathway molecules in antral follicles of high- and low-fecundity Hu sheep. Animal Reproduction Science 120 47-55. (doi:10.1016/j.anireprosci.2010.02.009)

Yan C, Wang P, DeMayo J, DeMayo FJ, Elvin JA, Carino C, Prasad SV, Skinner SS, Dunbar BS, Dube JL et al. 2001 Synergistic roles of bone morphogenetic protein 15 and growth differentiation factor 9 in ovarian function. Molecular Endocrinology 15 854-866. (doi:10.1210/me.15.6.854)

Young JM, Juengel JL, Dodds KG, Laird M, Dearden PK, McNeilly AS, McNatty KP \& Wilson T 2008 The activin receptor-like kinase 6 Booroola mutation enhances suppressive effects of bone morphogenetic protein 2 (BMP2), BMP4, BMP6 and growth and differentiation factor-9 on FSH release from ovine primary pituitary cell cultures. Journal of Endocrinology 196 251-261. (doi:10.1677/JOE-07-0148)

Zhao ZZ, Painter JN, Palmer JS, Webb PM, Hayward NK, Whiteman DC, Boomsma DI, Martin NG, Duffy DL \& Montgomery GW 2008 Variation in bone morphogenetic protein 15 is not associated with spontaneous human dizygotic twinning. Human Reproduction 23 2372-2379. (doi:10.1093/humrep/den268)

Received 19 December 2012

First decision 4 March 2013

Revised manuscript received 7 May 2013

Accepted 24 June 2013 